\title{
Response of NPK fertigation on pheno-physiological status of Citrus sinensis Osbeck cv. Mosambi under high density planting
}

\author{
Vishal Nirgude $^{1 *}$, K. Karuna ${ }^{1}$, Abhay Mankar ${ }^{1}$, Vikash Kumar ${ }^{1}$, Maggidi Spandana ${ }^{2}$ \\ ${ }^{1}$ Department of Horticulture (Fruit \& Fruit Technology), Bihar Agricultural University, Sabour- 813210 (Bihar), \\ INDIA \\ ${ }^{2}$ Department of Horticulture (Fruit \& Fruit Technology) ASPEE College of Horticulture \& Forestry, Navsari \\ Agricultural University, Navsari -396450 (Gujrat), INDIA \\ *Corresponding author. E-mail: nirgude.v7hort@gmail.com
}

Received: January 07, 2016; Revised received: April 27, 2016; Accepted: July 21, 2016

\begin{abstract}
The field experiment was conducted during 2013-14 to study the effects of fertigation on the phenology and physiological status of Citrus sinensis cv. Mosambi. The experiment was laid out in randomized block design with seven fertigation level, viz. $\mathrm{T}_{1}-120 \%$ of RDF; $\mathrm{T}_{2^{-}} 100 \%$ of RDF; $\mathrm{T}_{3^{-}} 80 \%$ of RDF; $\mathrm{T}_{4^{-}} 60 \%$ of $\mathrm{RDF} ; \mathrm{T}_{5^{-}} 40 \%$ of RDF; $T_{6}$ - Full dose in basal with drip irrigation and $T_{7}$ - Full dose in basal without drip irrigation and each treatment were replicated three times. Results obtained showed that increase in plant height $(36.75 \mathrm{~cm})$, trunk girth $(4.67 \mathrm{~cm})$, canopy volume $\left(1.83 \mathrm{~m}^{3}\right)$, leaf area index (5.51) and growth of current season shoot $\left(9.42 \mathrm{~cm}^{2}\right)$ of the plant were more responsive to higher dose of fertigation i.e. $T_{1}$ followed by $T_{2}$. The treatment effect was not marked on reproductive growth as expressed in terms of bud emergence, full bloom, fruit set and duration of bud emergence to maturity. The tree physiological parameters viz. total chlorophyll $(2.65 \mathrm{mg} / \mathrm{g})$, net photosynthesis rate $\left(6.83 \mu \mathrm{mol} \mathrm{CO}_{2} /\right.$ $\left.\mathrm{m}^{2} / \mathrm{sec}\right)$, stomatal conductance $\left(0.18 \mathrm{~mol} / \mathrm{m}^{2} / \mathrm{sec}\right)$ and leaf area $\left(31.9 \mathrm{~cm}^{2}\right)$ were also higher under treatment receiving higher dose of fertigation i.e. $T_{1}$. Therefore, on the basis of results obtained, treatment $120 \%$ RDF found superior in maintaining pheno-physiological status of mosambi plant under high density planting.
\end{abstract}

Keywords: Citrus, Fertigation, Phenology, Physiology.

\section{INTRODUCTION}

Citrus is one of the most popular fruit of tropical and sub-tropical region of the world and number one group of fruits grown in more than 140 countries in the world (Shirgure, 2012). It has appreciated not only for its beautiful appearance and pleasing flavour but also for its excellent food, juice, nutritional and medicinal properties. The geographical situation of India by possessing different types of climate permits to grow all types of horticultural crops. Increase in fruit production and productivity in India is major task at present in order to fulfil the minimum requirements first and thereafter lessen the pressure on cereals which helps in solving the food problems.

Nutritional requirement are essential for high density orchard of citrus crops. Fertigation is one of the most advance and efficient practice for enhancing fertilizer management, which includes application of water soluble fertilizers through drip irrigation system directly to the plant roots. Apart from this, it includes application of fertilizers in small and frequent doses that fit within scheduled irrigation intervals matching the plant water use to avoid leaching. It has also potential in enhancing use efficiency of water and fertilizer, control of nutrient concentration in soil solution and saving in applica- tion cost (Solaimalai et al., 2005 and Singh et al., 2010). There is limited scope for bringing new area under cultivation and hence more emphasis will be given on increasing the yield per unit area. Hence in Indian condition, where population pressure is more and land is inadequate, another strategy such as high density orchard system should be recommended as compared to scatter kind of planting system to achieve maximum yield from same piece of land (Choudhary, 1984).

Out of essential elements, nitrogen, phosphorus and potassium are called critical elements in any manurial programme. These elements are required in relatively large amount due to their major role in fundamental structure and various metabolic functions of plant. Nitrogen is mainly responsible for the growth attributes and occurs as nucleoprotein, amino acid, amines, amino sugars, polypeptide and helps in many other metabolic functions of a plant. Phosphorus is comparatively prominent as a plant nutrient than many other elements with their both organic and inorganic form available in the soil. It is a constituent for many compounds of the plants such as nucleic acid, phytins, and phospholipids and the co-enzymes, nicotinamide adenine dinucleotide (NAD), nicotinamide adenine dinucleotide phosphate (NADP) and adenosine tri phosphate (ATP). Potassium acts as a co-factor for many 
enzymes and plays a vital role in plant metabolism such as regulation of transpiration and water condition in the plant cells. It is also essential in certain enzymatically catalyzed and in the coupling of certain amino acids to form peptides (Sah et al., 2014).

Citrus plants are more sensitive to the deficiency of certain elements than many other cultivated crops. Adequate information on fertilizer requirement of different citrus species is lacking in India. Drip irrigation and fertigation are the most efficient methods of modern irrigation systems which have a potential advantage of water and fertilizer saving. (Koo, 1981; Haynes, 1985 and Shirgure, 2013). The efficient use of water and fertilizer to increase the crop yield is important concern in today's citricultural system (Shirgure, 2012). Furthermore, Citrus sinensis osbeck cv. Mosambi have shown good performance in scattered planting under Bihar conditions, the crop has shown promise in bearing at Sabour condition but there is lack of knowledge about its proper fertigation scheduling at different stages of growth and age of plant for better growth and yield. In view of the above, the present investigation was carried out to study the response of NPK fertigation on pheno-physiological status of $C$. sinensis osbeck cv mosambi under high density planting to work out proper fertigation practices under high density orchard system.

\section{MATERIALS AND METHODS}

Field location: The field experiment was carried out at high density orchard of the permanent experimental area of Bihar agricultural university $\left(87^{\circ} 2^{\prime} 42^{\prime}\right.$ E, $25^{\circ}$ $\left.15^{\prime} 40^{\prime \prime} \mathrm{N}\right)$ at Sabour, Bihar, at an altitude of $46 \mathrm{~m}$ above mean sea level in the heart of vast IndoGangatic plains of North India, during 2013-14. The climate of this place is sub-tropical of slightly semiarid nature. It is characterized by dry summer, moderate rainfall and cold winter (Table 4). The soil of the experimental plot had well drained sandy loam texture with good fertility and levelled surface.

Treatment details: The experiment was laid out in randomized block design with seven fertigation level based on recommended dose of fertilizer (RDF) i.e. 300:90:90 gram/ plant/ year, the treatments were $\mathrm{T}_{1}$ $120 \%$ of RDF $(360: 108: 108 \mathrm{~g}) ; \mathrm{T}_{2}-100 \%$ of $\mathrm{RDF}$ (300:90:90g); $\mathrm{T}_{3}-80 \%$ of RDF $(240: 72: 72 \mathrm{~g}) ; \mathrm{T}_{4}-60 \%$ of RDF (180:54:54g); $\mathrm{T}_{5}-40 \%$ of RDF (120:36:36g); $\mathrm{T}_{6}$ - Full dose (300:90:90g) in basal with drip irrigation and $\mathrm{T}_{7}-$ Full dose $(300: 90: 90 \mathrm{~g}$ ) in basal without drip irrigation and each treatment were replicated three times with four plant in each replication. The treatment $\mathrm{T}_{1}, \mathrm{~T}_{2}, \mathrm{~T}_{3}, \mathrm{~T}_{4} \mathrm{~T}_{5}$ were applied in split doses whereas, treatment $T_{6}$ and $T_{7}$ supplied directly in plant basin. Fertigation scheduling was administrated at monthly interval starting from November (Table 5). The fertilizer source used for fertigation were urea for nitrogen and mono potassium phosphate and sulfate of potash for phosphorus and potassium. The four year old mosambi plants were planted under high density planting (HDP), at a spacing of $3.0 \times 2.5 \mathrm{~m}$ apart.

Procedure: The phenological parameters viz. plant height, trunk girth, canopy volume, growth of current season shoot of 12 randomly selected plants from each treatment was measured with the help of measuring tape before and after fertigation during August. Further the canopy volume was calculated according formula given by Roose et al. (1986). The leaf area index (LAI) of selected plants was measured using the instrument canopy analyser (LP-80, PAR/LAI Ceptometer, Decagon Devices, Inc., WA, USA). The reproductive or fruiting parameters were recorded by visiting the experimental orchard frequently after bud emergence to fruit maturity. The physiological parameters in terms of leaf area of fifty fully expanded leaves from each treatment was recorded using leaf area meter (CI-203 CA, CID Bio-sciences, Camas, USA). The total chlorophyll content of the leaves was analysed following the method of Barnes et al. (1992). In which the fully mature (August-September) open leaf was taken as the experimental sample for chlorophyll estimation. The rate of photosynthesis, stomatal conductance, transpiration rate and internal $\mathrm{CO}_{2}$ concentration of mature leaves of 12 randomly selected plants was measured by portable photosynthesis system (LICOR - 6400 XT, Lincoln, NE, USA) by using IRGA (Infra-red gas analyser) during August-September. The leaf relative water content (RWC \%) in the recently mature leaves (August-September) was determined using the method suggested by Weatherley (1950).

Statistical analysis: The experimental data were subjected to statistical analysis in order to find out which of the treatments showed significant variation in different parameters studied under investigation. The technique of analysis of variance (ANOVA) for randomized block design (RBD) was adopted as suggested by Panse and Sukhatme (1967).

\section{RESULTS AND DISCUSSION}

\section{Phenology parameters}

Growth parameter: Data indicates that vegetative parameters were significantly influenced by different fertigation treatments (Table 1). The treatment $T_{1}$ showed the maximum plant height $(36.75 \mathrm{~cm})$ which has shown superior to rest of the treatments followed by $29.33 \mathrm{~cm}$ under $\mathrm{T}_{2}$. However, the lowest plant height $(18.50 \mathrm{~cm})$ was observed in $\mathrm{T}_{5}$ followed by $(24.62 \mathrm{~cm})$ in $\mathrm{T}_{6}$. Canopy volume was reported highest $\left(1.83 \mathrm{~m}^{3}\right)$ under treatment $\mathrm{T}_{1}$ followed by $1.72 \mathrm{~m}^{3}$ in $\mathrm{T}_{2}$ and found statistically at par to each other. The highest Leaf area index (5.51) was recorded in treatment $T_{1}$ followed $T_{2}, T_{3}$ and these treatments were found statistically at par. The maximum trunk girth $(4.67 \mathrm{~cm})$ was reported in $\mathrm{T}_{2}$ followed by $4.58,4.42,4.33 \mathrm{~cm}$. in $\mathrm{T}_{1}$, $\mathrm{T}_{3}, \mathrm{~T}_{4}$ respectively and these values were found at par 
Vishal Nirgude et al. / J. Appl. \& Nat. Sci. 8 (3): 1306 - 1311 (2016)

Table 1. Effect of fertigation on phenological (growth) parameters of $C$. sinensis cv. Mosambi.

\begin{tabular}{cccccc}
\hline Treatments & $\begin{array}{c}\text { Plant height } \\
(\mathbf{c m})\end{array}$ & $\begin{array}{c}\text { Trunk girth } \\
(\mathbf{c m})\end{array}$ & $\begin{array}{c}\text { Canopy volume } \\
\left(\mathbf{m}^{\mathbf{3}}\right)\end{array}$ & $\begin{array}{c}\text { Leaf Area } \\
\text { Index }\end{array}$ & $\begin{array}{c}\text { Growth of current } \\
\text { season shoot }\left(\mathbf{c m}^{2}\right)\end{array}$ \\
\hline 120\% RDF & 36.75 & 4.58 & 1.83 & 5.51 & 9.11 \\
100\% RDF & 29.33 & 4.67 & 1.72 & 5.13 & 7.42 \\
80\% RDF & 24.92 & 4.42 & 1.28 & 5.05 & 7.33 \\
60\% RDF & 25.67 & 4.33 & 1.45 & 4.84 & 8.34 \\
40\% RDF & 18.50 & 4.00 & 1.35 & 4.02 & 8.65 \\
100 \% RDF with drip & 24.62 & 4.20 & 1.71 & 4.35 & 6.83 \\
irrigation & & & & \\
100 \% RF without & 26.22 & 4.00 & 1.63 & 4.35 & 0.94 \\
drip irrigation & 2.99 & 0.38 & 0.19 & 0.51 & 6.50 \\
C.D. at 5\% & 6.26 & 5.33 & 6.88 & 5.98 & 0.43 \\
C.V. $(\%)$ & 1.37 & 0.17 & 0.08 & 0.23 & \\
SEm $( \pm)$ &
\end{tabular}

whereas the minimum trunk girth $(4.00 \mathrm{~cm})$ was reported under $\mathrm{T}_{5}$ and $\mathrm{T}_{7}$. The maximum growth of current season shoot $\left(9.42 \mathrm{~cm}^{2}\right)$ was recorded in $\mathrm{T}_{2}$ followed by $\mathrm{T}_{1}$ and $\mathrm{T}_{6}$ and these treatments had nonsignificant difference due to different treatments, while the treatment $\mathrm{T}_{7}$ had the minimum growth of shoot $(6.83 \mathrm{~cm})$ followed by $\mathrm{T}_{3}$ and $\mathrm{T}_{4}$ and these values were found statistically at par. The increased growth parameters recorded under $T_{1}$ and $T_{2}$ fertigation treatments due to increased nutrient requirement under high density planting of citrus crop, in addition to this, present investigation revealed that nutritional requirement at Sabour, Bihar condition was found still high and it is due to the fact that the before experiment NPK status of the soil was found low and it might have results in uptake of more nutrient from same piece of land (Table 6). Furthermore, there was a continuous supply of nutrients in fertigation as the fertilizers were applied in 15 split doses during the entire growth period of the plants, which might have helped in meeting the requirements of nutrients during the critical period of growth. These above findings are in accordance with Ramana et al. (2014) who obtained highest plant growth parameters i.e. plant height (3.09 $\mathrm{m})$, stem girth and canopy volume $\left(20.9 \mathrm{~m}^{3}\right)$ when higher dose of NPK were applied in sweet orange. Kachwaya and Chandel (2015) reported that higher doses of NPK $(150,100,120 \mathrm{~kg} / \mathrm{ha}$.) through fertigation increased growth parameters like maximum fruit length $(42.49 \mathrm{~mm})$, fruit breadth $(31.74 \mathrm{~mm})$ and fruit weight $(19.87 \mathrm{~g})$ in strawberry cv. Chandler. Ahmad et al. (2010) also observed that vegetative growth was positively related to the amount of nitrogen applied through drip fertigation in sweet cherry. The findings in relation to canopy volume was found agreement with results of Menino et al. (2003), who found that application of nitrogen at higher rate i.e. $720 \mathrm{~g} \mathrm{~N}$ leads to the greatest tree canopy volume in Valencia trees. The highest value of LAI with the $\mathrm{T}_{1}$ may be due to the effect of nitrogen, the findings in relation to LAI by nitrogen application were supported by Chatterjee
(2013) in Tomato.

Reproductive parameter: The finding in relation to influence of different fertigation treatments on the reproductive phase of mosambi plant was carefully observed and presented in Table 2. The information of time and length of flowering is pre-requisite for taking up a crop improvement programme through hybridization. Although the variation was not very significant due to different treatment, still a trend was there under such observation. In general with increase in level of nitrogen, bud emergence showed a tendency to get delayed because it make plant to survive under vegetative condition for longer period and ultimately delayed flowering occurred whereas, phosphate stimulate flowering and adds in fruit setting and hence, a balanced combination of NPK was found necessary to induced early flowering and fruiting of citrus plant. Wassel et al. (2007) observed that initial and final fruit setting were increased by raising the amount of nitrogen fertilization. Whereas, a balance dose of phosphate and potash may enhance the anthesis period for better fruit setting, hence a combination of NPK fertilization results in early fruit setting. The similar findings in relation to early flowering and fruiting due to combined NPK fertilization was reported by Sah et al. (2014) in pear. Maturity of fruit was also influenced more or less on a similar pattern. The fruit maturity was observed to be delayed with increase in level of nitrogen, this may be due to the fact that excess nitrogen may produce large fruits with thick skin (Jacob and Uexkull, 1958) and consequently delayed the maturity. The effect of phosphorus in respect of decreasing the period of maturity was more pronounced (Lekvinadze (1972) and Ghosh et al. (1981). Phosphate and potash also play an important role in balancing the effect of nitrogen and therefore, combination of NPK have tendency to balance maturity of fruits at all levels of nitrogen, the results is in agreement with findings of Choudhary (1984) in mosambi.

Physiological parameters: The physiological characters of mosambi plant were significantly influenced by 
Vishal Nirgude et al. / J. Appl. \& Nat. Sci. 8 (3): 1306 - 1311 (2016)

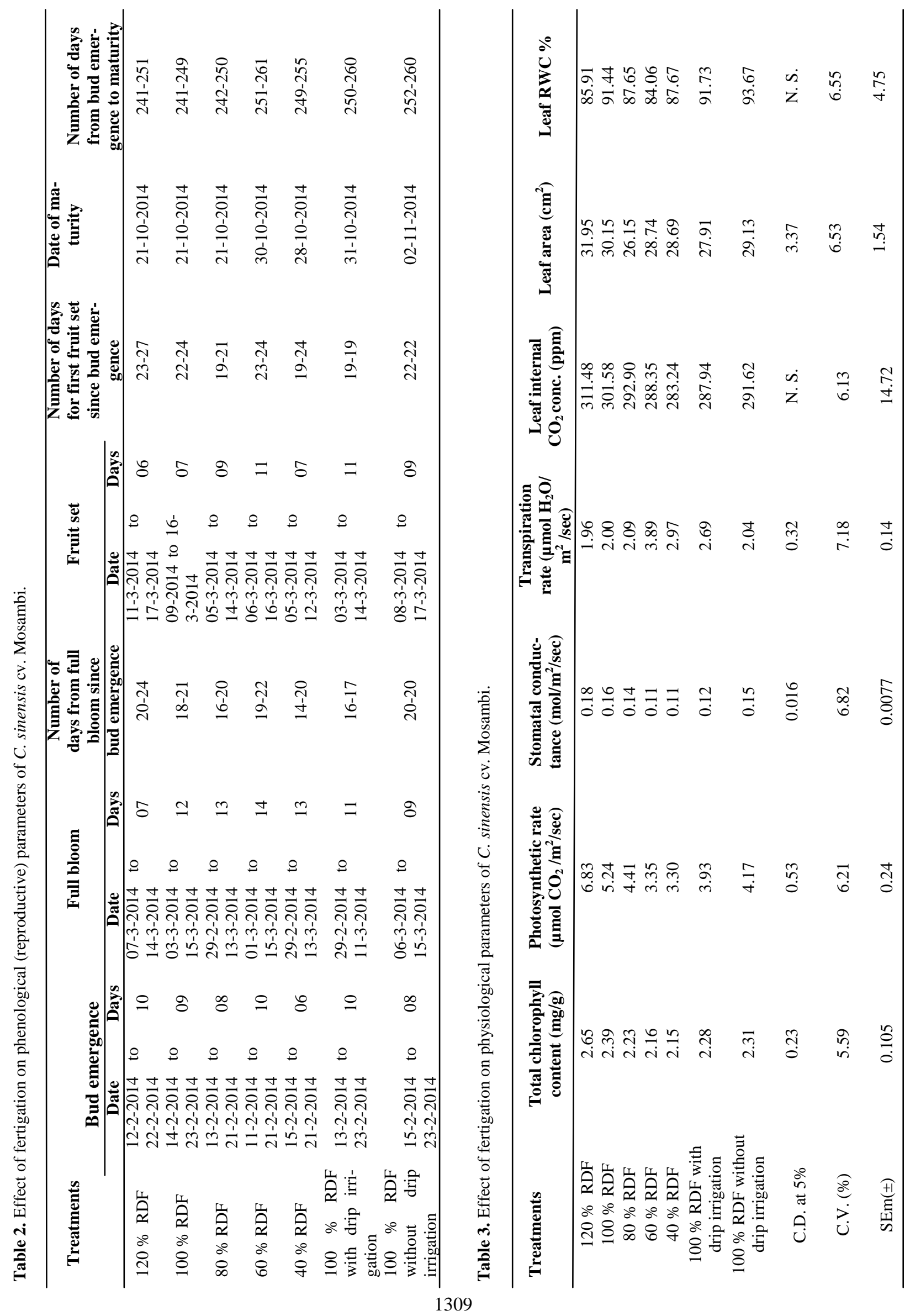


Table 4. Meteorological data of the year 2013-14.

\begin{tabular}{|c|c|c|c|c|c|c|}
\hline \multirow{2}{*}{ Months } & \multicolumn{2}{|c|}{ Temperature $\left({ }^{\mathbf{0}} \mathrm{C}\right)$} & \multicolumn{2}{|c|}{ Relative Humidity (\%) } & \multirow{2}{*}{$\begin{array}{c}\text { Rainfall } \\
\text { (cm) }\end{array}$} & \multirow{2}{*}{$\begin{array}{c}\text { Wind Velocity } \\
(\mathrm{Km} / \mathrm{hr} .)\end{array}$} \\
\hline & Max. & Min. & $7.00 \mathrm{AM}$ & $2.00 \mathrm{PM}$ & & \\
\hline Nov, 13 & 26.9 & 15.3 & 89.0 & 59.0 & 1.42 & 1.0 \\
\hline Dec, 13 & 23.4 & 10.1 & 98.0 & 62.0 & 0.0 & 1.2 \\
\hline Jan, 14 & 20.2 & 10.4 & 95.0 & 69.0 & 0.1 & 3.5 \\
\hline Feb, 14 & 22.7 & 10.9 & 91.6 & 59.7 & 1.2 & 3.6 \\
\hline Mar, 14 & 30.0 & 15.3 & 77.2 & 41.0 & 0.1 & 3.7 \\
\hline April, 14 & 37.0 & 20.0 & 62.2 & 29.9 & 0.0 & 5.4 \\
\hline May, 14 & 37.8 & 24.3 & 65.1 & 41.2 & 6.0 & 8.2 \\
\hline June, 14 & 34.2 & 24.5 & 83.6 & 61.4 & 4.1 & 5.5 \\
\hline July, 14 & 32.3 & 25.3 & 88.8 & 77.2 & 16.5 & 7.1 \\
\hline Aug, 14 & 32.4 & 24.9 & 89.3 & 78.0 & 7.5 & 5.6 \\
\hline Sept, 14 & 32.2 & 23.0 & 88.0 & 77.1 & 4.5 & 4.0 \\
\hline Oct, 14 & 32.3 & 20.5 & 87.2 & 67.8 & 0.1 & 2.1 \\
\hline
\end{tabular}

Source: Agro-meteorology department, Bihar Agricultural University, Sabour

Table 5. Time line chart for fertigation scheduling of N, P and $\mathrm{K}$ fertilizers in $C$. sinensis cv. Mosambi.

\begin{tabular}{ccccc}
\hline Month & Date & N & P & K \\
\hline January & 15 & - & - & - \\
February & 15 & $\checkmark$ & & - \\
March & 15 & $\checkmark$ & $\checkmark$ & $\checkmark$ \\
April & 15 & $\checkmark$ & $\checkmark$ & $\checkmark$ \\
May & 15 & $\checkmark$ & - & $\checkmark$ \\
June & 15 & $\checkmark$ & - & $\checkmark$ \\
July & 15 & - & - & $\checkmark$ \\
August & 15 & - & - & $\checkmark$ \\
September & 15 & - & - & - \\
October & 15 & - & - & - \\
November & 15 & - & & - \\
December & 15 & - & - & - \\
\hline
\end{tabular}

different fertigation treatments. The results (Table 3) showed that there was significant variation in total chlorophyll content among different treatments. The maximum total chlorophyll content $(2.65 \mathrm{mg} / \mathrm{g})$ was recorded in treatment $T_{1}$ which has shown superior to rest of the treatments followed by $2.39 \mathrm{mg} / \mathrm{g}$ under $\mathrm{T}_{2}$, whereas, the minimum chlorophyll content $(2.15 \mathrm{mg} / \mathrm{g})$ was recorded in $\mathrm{T}_{5}$ and found at par with $\mathrm{T}_{3}, \mathrm{~T}_{4}, \mathrm{~T}_{6}$ and $\mathrm{T}_{7}$. The highest photosynthesis rate $\left(6.83 \mu \mathrm{mol} / \mathrm{m}^{2} /\right.$ sec.) was recorded under $\mathrm{T}_{1}$ followed by 5.24 and 4.41 $\mu \mathrm{mol} / \mathrm{m}^{2} / \mathrm{sec}$. under treatment $\mathrm{T}_{2}$ and $\mathrm{T}_{3}$ respectively. However, minimum photosynthesis rate $(3.30 \mu \mathrm{mol} /$ $\mathrm{m}^{2} / \mathrm{sec}$.) was recorded in $\mathrm{T}_{5}$ which was statistically found at par with $\mathrm{T}_{4}$. The stomatal conductance was found maximum $\left(0.18 \mu \mathrm{mol} / \mathrm{m}^{2} / \mathrm{sec}\right.$. $)$ in $\mathrm{T}_{1}$ followed by $0.16 \mu \mathrm{mol} / \mathrm{m}^{2} / \mathrm{sec}$. under $\mathrm{T}_{2}$, whereas, minimum stomatal conductance $\left(0.11 \mu \mathrm{mol} / \mathrm{m}^{2} / \mathrm{sec}\right.$. $)$ was noticed in leaves of treatment $\mathrm{T}_{4}$ and $\mathrm{T}_{5}$ and found at par with $\mathrm{T}_{6}$. The maximum transpiration rate $\left(3.89 \mu \mathrm{mol} / \mathrm{m}^{2} /\right.$ sec.) was recorded in $\mathrm{T}_{4}$. Whereas, minimum transpiration rate $\left(1.96 \mu \mathrm{mol} / \mathrm{m}^{2} / \mathrm{sec}\right.$. $)$ was recorded in $\mathrm{T}_{1}$, which were found statistically at par with $T_{2}, T_{3}$ and $T_{7}$. The treatment $T_{1}$ showed highest $\left(31.95 \mathrm{~cm}^{2}\right)$ leaf area and it was found statistically at par with $\mathrm{T}_{2}, \mathrm{~T}_{4}, \mathrm{~T}_{5}$ and $\mathrm{T}_{6}$. Whereas, minimum leaf area was recorded under $T_{3}$. The data in relation to internal $\mathrm{CO}_{2}$ concentration and relative water content of leaves were found statistically non-significant by different level of fertilizer treat-
Table 6. Soil status of experimental land before treatment with different dose of fertilizers.

\begin{tabular}{ccc}
\hline Soil Depth (cm) & $0-15$ & $15-30$ \\
$\mathrm{pH}(1: 2.5)$ & 7.37 & 7.24 \\
$\mathrm{EC}(\mathrm{ds} / \mathrm{m})$ & 0.42 & 0.40 \\
Organic $\mathrm{C}(\%)$ & 0.53 & 0.46 \\
$\mathrm{~N}(\mathrm{Kg} /$ ha. $)$ & 213.50 & 194.45 \\
$\mathrm{P}_{2} \mathrm{O}_{5}(\mathrm{Kg} /$ ha. $)$ & 29.75 & 27.50 \\
$\mathrm{~K}_{2} \mathrm{O}(\mathrm{Kg} /$ ha. $)$ & 165.25 & 134.77 \\
\hline
\end{tabular}

ments. Nitrogen is an integral part of many compounds, including chlorophyll, nucleic acid, proteins and enzymes and found essential for plant growth and development (Sah et al., 2014). The pyrole rings of chlorophyll arise after prior combination of amino acids, glycine and succinic acid. Nitrogen application increases chlorophyll content, which results in production of photosynthates. Intrigliolo et al. (1992) found that continuous fertigation significantly improved physiological plant status like photosynthesis rate, transpiration rate and stomatal conductance in citrus tree. (Leuning, 1995) found that the rate of photosynthesis, required supply of $\mathrm{CO}_{2}$ and stomatal conductance of leaves are highly correlated to intensity of light, which subsequently increase with higher leaf area. The increase in leaf area may be due to the positive effect of nitrogen on many important plant structures, genetic and metabolic compounds in plant cells (Don, 2001). In present investigation, nutrient application through fertigation resulted in maintaining optimum moisture and nutrient content of soil and hence, responsible for better physiological activity of citrus plant whereas, under water deficit condition plant close their stomata to prevent dehydration which affects both transpiration and photosynthesis in citrus (Medina et al., 1999). The leaf relative water content was found non-significant among different treatments which might be due to light, temperature and stress conditions during the period of investigation.

\section{Conclusion}

The study has revealed that the application of fertigation with NPK at the dose of $120 \%$ RDF 
(360:108:108g/plant/year) gave the highest plant height, canopy volume, LAI, total chlorophyll content, photosynthesis, stomatal conductance and leaf area in Citrus sinensis Osbeck cv. mosambi under high density planting condition. Hence, treatment $120 \%$ RDF can be recommended under sabour, Bihar, India agro-climatic conditions for growing sweet orange crop to fetch higher returns.

\section{ACKNOWLEDGEMENTS}

The authors acknowledge the receipt of all kind of help and support rendered by Head and Chairman, Department of Horticulture (Fruit \& Fruit technology), Bihar Agricultural University, Sabour, India, for all the required infrastructure and facilities and time-to-time suggestion in making the assignment successful. We also acknowledge funding support from the Indian Council of Agricultural Research for providing ICAR- Junior Research Fellowship.

\section{REFERENCES}

Shirgure, P.S. (2012). Micro-irrigation systems, automation and fertigation in Citrus. Scientific J. Rev., 1 (5): 156-169.

Singh, R.M., Singh, D.K., and Rao, K.V.R. (2010). Fertigation for increased crop yield and fertilizer saving. Agric. Engi. Today, 34 (2).

Solaimalai, A., Baskar, M., Sadasakthf, A. and Subburamu, K. (2005). Fertigation in high value crops - A review. Agric. Rev., 26 (1): 1-13.

Choudhary, R. (1984). The effects of selective combination of $\mathrm{N}, \mathrm{P} \& \mathrm{~K}$ on growth, yield and quality of sweet orange (Citrus sinensis, Osbeck) cv. Mosambi. M. Sc. Thesis, Rajendra Agricultural University, BAC, Sabour, Bihar.

Sah, H., Pratibha, Kumar, R. and Topwal, M. (2014). Response of NPK on growth, yield and quality of oriental pear: A Review. Indian Hort. J., 4 (1): 01-08.

Koo, R.C.J. (1981). Results of citrus fertigation studies. Proc. Florida Stat. Hort. Soci., 93: 33-36.

Haynes, R.J. (1985). Principles of fertilizer use for trickle irrigated crops. Ferti. Res., 6: 235-255.

Shirgure, P.S. (2013). Yield and fruit quality of Nagpur mandarin (Citrus reticulata Blanco) as influenced by evaporation based drip irrigation schedules. Scientific J. Crop Sci., 2 (2): 28-35.

Roose, M.L., Col, D.A., Atkin, D. and Kuper, R.S. (1986). Yield and tree size of four citrus cultivars on 21 root stocks in California. J. Amer. Soci. Hort. Sci., 114: 135-140.

Barnes, J.D., Balaguer, L., Manrique, E., Elvira, S. and Davison, A.W. (1992). A reappraisal of the use of DMSO for the extraction and determination of chlorophylls $\mathrm{a}$ and $\mathrm{b}$ in lichens and higher plants. Environ. Experi. Bot., 32: 85-100.

Weatherley, P.E. (1950). Studies in the water relations of the cotton plant. I. The field measurement of water deficits in leaves. New Phytol., 49: 81-87.

Panse, V.G. and Sukhatme, P.V. (1967). Statistical methods for agricultural workers, Indian Council of Agricultural Research, New Delhi.

Ramana, K.T.V., Lakshmi, L.M., Gopal, K., Krishna, V.N.P.S., Lakshmi, T., Sarada, G., Gopi, V. and Sankar, T.G. (2014). Nitrogen and Potassium Based Fertigation Response on Plant Growth, Yield and Quality of Sweet Orange (Citrus sinensis Osbeck) cv. Sathgudi. Research and Reviews: J. Agric. Allied Sci., 3 (3).

Kachwaya, D.S. and Chandel, J.S. (2015). Effect of fertigation on growth, yield, fruit quality and leaf nutrients content of strawberry (Fragaria $\times$ ananassa) cv. Chandler. Indian J. Agric. Sci., 85 (10): 1319-23.

Ahmad, M.F., Samantan, A. and Jabeen, A. (2010). Response of sweet cherry (Prunus avium) to fertigation of nitrogen, phosphorus and potassium under Kerawa land of Kashmir valley. Indian J. Agric. Sci., 80 (6): 512-516.

Menino, M.R., Corina, C., Amarilis, V., Victor, V.A. and Jose, B. (2003). Tree size and flowering intensity as affected by nitrogen fertilization in non-bearing orange trees grown under Mediterranean conditions. $J$. Plant Physiol., 160: 1435-1440.

Chatterjee, R. (2013). Physiological attributes of tomato (Lycopersicon esculentum Mill.) influenced by different sources of nutrients at foothill of eastern $\mathrm{Hi}$ malayan region. J. Appl. Natur. Sci., 5 (2): 282-287.

Wassel, A.H., Ahmed, F.F., Ragab, M.A. and Ragab, M.M. (2007). Response of Balady mandarin trees to drip irrigation and nitrogen fertigation II- Effect of nitrogen fertigation and drip irrigation on fruit setting, number and quality of fruits of Balady mandarin trees (Citrus reticulata). Afric. Crop Sci. Conf. Proc., 8: 513-522.

Jacob, A. and Uexkull, H.V. (1958). Fertilizer usenutrition and manuring of tropical crops. Centre d'Etude de Azote, Hannover.

Lekvinadze, P.A. (1972). The effect of different superphosphate rates on some quality indices in satsumas. Subtropicheskie Kul' tury, (5): 83-88.

Ghosh, S.P., Verma, A.N. and Govind, S. (1981). Rejuvenating citrus orchards in North- Eastern Hill region, Indian J. Hort., 26(1): 20-24.

Intrigliolo, F., Coniglione, L. and Germana, C. (1992). Effect of fertigation on some physiological parameters in Orange trees. In: Proc. Inter. Soci. Citricul., Tribulato E., Gentile A. and G. Refergiato (eds). Mar. 8-13, Acireale. Italy. 2. pp.584-589.

Leuning, R. (1995). A critical appraisal of a combined stomatal-photosynthetic model for $\mathrm{C}_{3}$ plants. Plant Cell Environ., 18: 339-355.

Don, E. (2001). Efficient fertilizer use nitrogen, IMC Global 4th Ed. III inois, USA. Pp.66-84.

Medina, C.L., Machado, E.C. and Gomes, M.M.A. (1999). Stomatal conductance, transpiration and photosynthesis Valencia orange under water deficiency. Rev. Bras. Physiol. Veg., 11: 29-34. 